\title{
The benthic macroinvertebrate fauna of highland streams in southern Brazil: composition, diversity and structure
}

\author{
Ludwig Buckup; Alessandra A. P. Bueno; Georgina Bond-Buckup; Marcelo Casagrande \& Fabiane Majolo
}

Departamento de Zoologia, Instituto de Biociências, Universidade Federal do Rio Grande do Sul. Avenida Bento Gonçalves

9500, prédio 43435, 91501-970 Porto Alegre, Rio Grande do Sul, Brasil. E-mail: Ibuckup@yahoo.com.br

\begin{abstract}
Benthic macroinvertebrate in four rivers, three in the Pelotas River basin (Divisa, Marco and Silveira rivers, in the headwaters of the Uruguai River) and one in the Taquari-Antas system (Antas River), a tributary in the Guaíba basin, in the state of Rio Grande do Sul, were identified. Two samples were collected in summer, autumn and spring, with one replicate in each river. The total of 28,961 specimens included members of Platyhelminthes, Annelida, Acarina, Insecta, Crustacea and Mollusca. The Silveira and Marco rivers showed significant differences in the indices of Shannon-Weaver $\left(\mathrm{H}^{\prime}\right)$, Simpson's Reciprocal (1/D), Margalef (DMg) and Equitability (E). The Silveira River showed the highest means of diversity and the EPT index (Ephemeroptera, Plecoptera, Trichoptera). Comparison among the diversity indices, considered individually, were insufficient to show differences in community structure, for the purpose of ecological characterization of the rivers. The EPT values characterized the Divisa River as having the highest abundance (73\%), followed by the Marco (71\%), Antas (48\%) and Silveira (36\%). These results suggest that the Silveira River is subject to moderate environmental stress, from human impact, although it showed the highest diversity of the major macrobenthic groups.

KEY WORDS. Aquatic invertebrates; community structure; diversity indices; Rio Grande do Sul.
\end{abstract}

RESUMO. Fauna de macro-invertebrados bentônicos de rios de montanha no sul do Brasil: composição, diversidade e estrutura. Os macro-invertebrados bentônicos que ocorrem em quatro rios, três pertencentes à bacia do Rio Pelotas (Rios Divisa, Marco e Silveira nas cabeceiras do Rio Uruguai) e um ao sistema TaquariAntas (Rio Antas), tributário da bacia do Guaíba, no Estado do Rio Grande do Sul, foram identificados. Duas amostras foram coletadas no verão, outono e primavera, com uma réplica em cada rio. Foram coletados 28961 espécimes de macro-invertebrados compreendendo Platyhelminthes, Annelida, Acarina, Insecta, Crustacea e Mollusca. Na comparação entre os rios, Silveira e Marco mostraram diferenças significativas nos índices de Shannon-Weaver $\left(\mathrm{H}^{\prime}\right)$, no Recíproco de Simpson (1/D), de Margalef (DMg) e na Equitabilidade (E). O rio Silveira possui os maiores índices médios de diversidade e de EPT (Ephemeroptera, Plecoptera, Trichoptera). Os valores de EPT caracterizaram o rio Divisa com a maior abundância (73\%), seguido pelo Marco (71\%), Antas (48\%) e Silveira (36\%), Estes resultados sugerem que o rio Silveira sofre um moderado stress ambiental, de origem antrópica, embora mostre uma maior diversidade da macrofauna bentônica.

PALAVRAS-CHAVE. Estrutura da comunidade; índices de diversidade; invertebrados aquáticos, Rio Grande do Sul.

The world's continental surface-water resources are receiving special attention from ecologists and governmental authorities, in many countries including Brazil (SAlati et al. 1999, TUNDISI et al. 1999). The environmental impacts that are threatening aquatic ecosystems necessitate immediate and profound expansion of our knowledge of the biotic structure of limnetic systems and the implementation of effective methods of monitoring.

On the world scene, Brazil occupies a special position because of the enormous freshwater discharge of its rivers, representing $53 \%$ of all limnetic water production in South America $\left(334,000 \mathrm{~m}^{3} / \mathrm{s}\right)$ and $12 \%$ of global production $\left(1,488.000 \mathrm{~m}^{3} / \mathrm{s}\right)$ (RebouÇAS 1999). The highlands of southern Brazil contain re- markable freshwater resources, whose quality, chiefly in the headwater areas, is mostly acceptable. These areas are of high biological importance (MMA 2000).

Several drainage basins have their headwaters in the highlands of Rio Grande do Sul; the largest, the Pelotas River, a tributary of the Uruguai River, defines the border with Argentina. A second basin, Taquari-Antas, is part of the Guaiba system, which drains into the Patos Lagoon. The grassy landscapes in these highlands contain enclaves of Araucaria (Juss , 1789) (Araucariaceae) forest, which are undergoing severe environmental impact from the intensive cultivation of exotic tree species, especially Pinus (Linnaeus, 1753) (Pinaceae). These trees

Revista Brasileira de Zoologia 24 (2): 294-301, junho 2007 
provide timber and cellulose for industries in Brazil and other countries.

Some streams in these basins are beginning to suffer strong impacts from forestry activities, mainly from uncontrolled discharge of the timber sawmills and destruction and/ or replacement of the native gallery forests. The effects can be seen in the elevation and silting of the streams, and the decrease in their biological diversity. In aquatic ecosystems of Scotland and South Island in New Zealand, the negative consequences of overexpansion of exotic conifer plantations on the benthic macroinvertebrate communities were elucidated by Harriman \& Morrison (1982) and Friberg et al. (1997).

Moreover, the unregulated application of pesticides in potato and apple agriculture is an increasingly preferred alternative to traditional practices. The introduction of exotic fish species, such as the rainbow trout Oncorhynchus mykiss (Walbaum, 1792), constitutes an additional menace to the native aquatic biota of the small streams of the drainage basins of the highland mountain meadows of Rio Grande do Sul.

Knowledge of benthic macroinvertebrates has been used by many researchers, such as the characterization of trophism and the functionality of aquatic environments (LENAT 1993, Kikuchi \& Uieda 1998, Melo \& Froehlich 2001, Galdean et al. 2001, BuENo et al. 2003) as well as the understanding of the trophic dynamics of food webs (Rosi-SHall \& Wallace 2002, Bueno \& BondBuckup 2004, MotTA \& UiEda 2005). Macroinvertebrates have also been much utilized as biotic indicators in monitoring (LENAT 1993, Charvet et al. 1998, Marques \& Barbosa 2001, Lorenz et al. 2004) and in evaluation of water quality (CALListo et al. $2001 \mathrm{a}, \mathrm{b}$ ). Human influence on the areas surrounding the streams has provided incentive for the study of impacts from organic pollution and/or water acidification caused by changes in agricultural practices (Harriman \& Morrison 1982, Lenat \& Crawford 1994, SPONSElLer et al. 2001), and estimation of the consequences of introduction of exotic plant species (Friberg et al. 1997). Additionally, many projects have been developed to compare streams at different altitudes and latitudes (JACOBSEN et al. 1997), describe the physical and chemical conditions in stream systems (REMPEL et al. 2000, Whiting 2002), set priorities and policies for land conservation (WRIGHT et al. 1993), and also evaluate the influence of the range of variation in streams on the macroinvertebrate faunas (Pardo \& Armitage 1997, Beisel et al. 1998, Boyero 2003), among other subjects.

Our objectives included a comparison between biodiversity and community structure in four highland streams, considering that until now no research on this subject has been done in the region.

\section{MATERIAL AND METHODS}

\section{Study area and sampling stations}

Local altitudes are over 1,200 meters, with low air temperatures and sporadic snowfall in the winter and mild temperatures during the summer. The regional climate is charac- terized as mesothermal and humid, with mild summers (Lemos $\&$ Santos 1986), super humid, or super humid to humid (IPAGro 1989). The annual rainfall during the study period ranged from 1,700 to $1,800 \mathrm{~mm}$, with little precipitation during autumn and winter and more in spring and summer. Mean low temperatures were below $0^{\circ} \mathrm{C}$ during both years. Mean annual high temperatures were 19.69 and $20.14^{\circ} \mathrm{C}$, with the highest single values of 28 to $30{ }^{\circ} \mathrm{C}$ during summer months (Tab. I).

The study site is located in the geomorphic area called the Planalto das Araucarias (Araucaria Plateau), the easternmost segment of the Morphostructural Domain Basin and Sedimentary Deposits (Domínio Morfoestrutural das Bacias e Coberturas Sedimentares), in acidic rocks of the Serra Geral Formation in southern Brazil (Governo do Estado de Santa Catarina 1986). Wide areas are covered by grassy fields of Andropogon lateralis (Nees, 1753) (Poacea), a dominant and locally important species; the other principal vegetation types are the Araucaria forests and highland peat bogs.

The headwater regions of the Taquari-Antas $\left(28^{\circ} 49^{\prime} \mathrm{S}\right.$ $\left.50^{\circ} 00^{\prime} \mathrm{W}\right)$ and of the Pelotas River system $\left(28^{\circ} 36^{\prime} \mathrm{S}-49^{\circ} 58^{\prime} \mathrm{W}\right)$ are subject to torrential rains, with rapid surface outflow and abrupt variations in discharge, resulting from the steeply sloped landscape; dense, radial drainage; sparse vegetation cover; and the relative shallowness and low permeability of the soils. The zones with less energy and accumulation of fine sediments are well spaced, representing a Rithral section, with low autochthonous production, and the typical, crystal-clear oligotrophic water of mountain streams.

\section{Macroinvertebrate collection and environmental measurements}

Three of the rivers sampled, Silveira, Marco and Divisa, belong to the Pelotas River basin; the Antas River is in the Antas-Taquari basin (Fig. 1).

Two samples were collected monthly, in each stream, using a Surber sampler $\left(1,089 \mathrm{~cm}^{2}\right.$ area), with $250 \mathrm{~mm}$ mesh netting, in different types of sediment and current speeds. Samples were grouped according to season, i.e., austral autumn 2000 (April and June), spring 2000 (September and October) and summer 2000-2001 (December and February), resulting in 12 samples. The intense rains in winter prevented sampling in that season. Sampling methods followed the recommendations of MerRIT \& Cummins (1984) and Bueno et al. (2003).

The following physical and chemical water parameters were measured: a) water temperature; b) oxygen content, with a hand-held Dissolved Oxygen Meter (OXI 330/SET-WTW; c) $\mathrm{pH}$, with a portable Cole \& Parmer $\mathrm{pH}$ Meter and d) conductivity, with a portable Model 33 S-C-T-Meter.

In the laboratory, the specimens were sorted and identified to family level, following the recommendations of JACOBSEN et al. (1997), Dolédec et al. (2000) and Melo (2005). Because of the paucity of taxonomic descriptions of Brazilian benthic invertebrates, it was difficult to identify the specimens to species level. Taxonomic identification was based on MAcan (1975) and Roldan-Pérez (1988).

Revista Brasileira de Zoologia 24 (2): 294-301, junho 2007 
Table I. Air temperature, rainfall, and relative humidity in São José dos Ausentes, Rio Grande do Sul State, Brazil, in 2000 and 2001.

\begin{tabular}{lcc}
\hline \multicolumn{1}{c}{ Meteorological data } & Year 2000 & Year 2001 \\
\hline Mean lowest air temperatures $\left({ }^{\circ} \mathrm{C}\right)$ & 8.83 & 9.92 \\
Absolute lowest air temperature during the period $\left({ }^{\circ} \mathrm{C}\right)$ & -8.20 & -4.20 \\
Mean highest air temperature $\left({ }^{\circ} \mathrm{C}\right)$ & 19.69 & 20.14 \\
Absolute highest air temperature during the period $\left({ }^{\circ} \mathrm{C}\right)$ & 28.80 & 30.00 \\
Rainfall $(\mathrm{mm})$ & $1,738.00$ & $1,885.40$ \\
Lowest and highest Rainfall during the period $(\mathrm{mm})$ & 54.6 (May), 307.3 (October) & 34.7 (August), 253.6 (September) \\
Mean air humidity (\%) & 77.66 & 77.75 \\
\hline
\end{tabular}

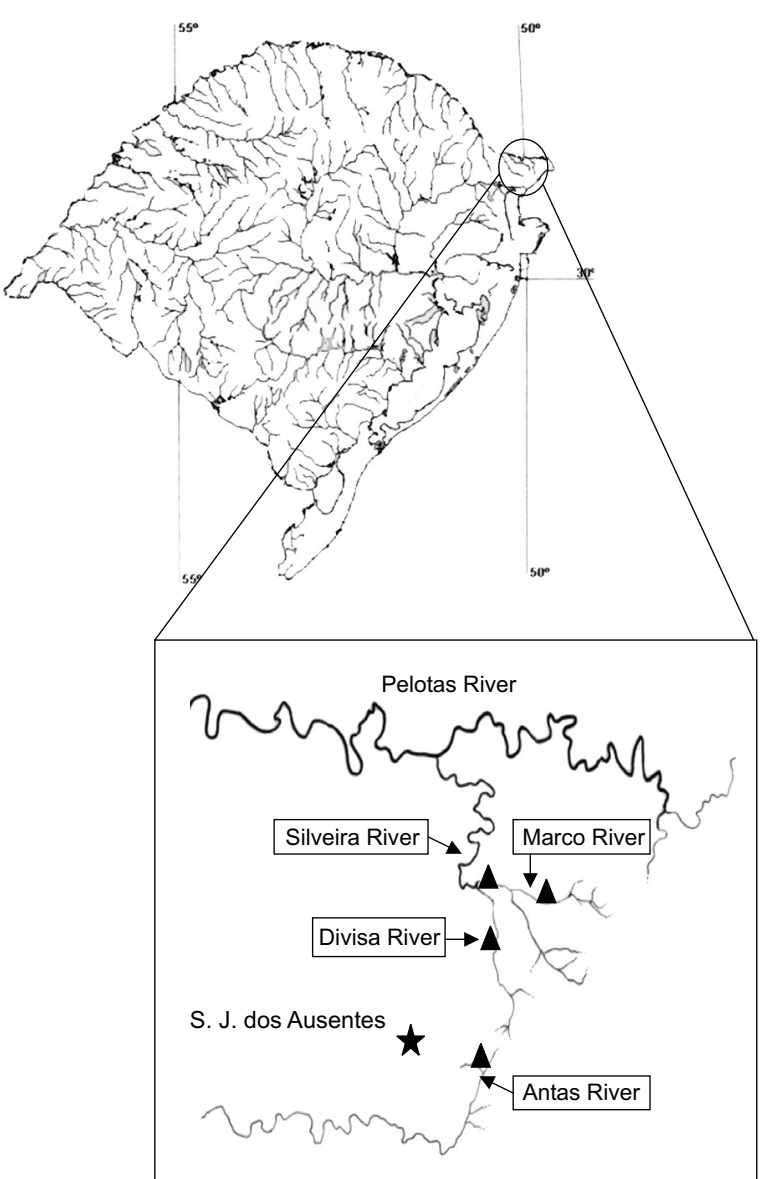

Figure 1. Map of Rio Grande do Sul, southern Brazil, showing the sample sites ( $\mathbf{\Delta})$ in Pelotas, Silveira, Marco, Divisa and Antas Rivers.

\section{Data analysis - community structure}

The following variables were analyzed: abundance - number of individuals per sample $(\mathrm{N})$; richness- number of families per sample (S); diversity - Shannon-Weaver index $\left(\mathrm{H}^{\prime}\right)$, Margalef's index $\left(\mathrm{D}_{\mathrm{Mg}}\right)$, Simpson's reciprocal index $(1 / \mathrm{D})$; evenness (E) or equitability; and number of families of EPT (Ephemeroptera, Plecoptera, Trichoptera), which is commonly utilized as an indicator of disturbance in stream communities
(SPONSELLER et al. 2001). The EPT proportion was calculated by dividing the number of individuals belonging to the EPT-Group by the total abundance in each stream.

The diversity in each stream was compared by season, and analyzed using One-Way ANOVA (SPSS for Windows version 10.0).

\section{RESULTS}

\section{Physical and chemical characteristics}

The four rivers are very similar in their characteristics as headwaters of mountain rivers, with bed sediments composed mainly of pebbles and, in some places, continuous basaltic flagstone, and stretches of swift current alternating with still water sections. Water temperature variation was very similar in the four streams during the year; the widest range, from 8.8 to $25^{\circ} \mathrm{C}$, was measured in the Silveira River. The $\mathrm{pH}$ was neutral or slightly alkaline at all stations, 6.5 in the Divisa River and 8.5 in the Silveira River. Mean conductivity was also low: 15 $\mathrm{mS} / \mathrm{cm}$ in Silveira, $20 \mu \mathrm{S} / \mathrm{cm}$ in Marco, $13 \mu \mathrm{S} / \mathrm{cm}$ in Divisa and $17 \mu \mathrm{S} / \mathrm{cm}$ in Antas. The dissolved oxygen percent saturation remained above $80 \%$, usually around $100 \%$ in all streams.

No statistically significant correlation was found between the abundance of organisms and the abiotic variables. This can be explained by the non-continuous point measurements of the physical and chemical conditions.

\section{Community Structure and Composition}

A total of 28,961 specimens, primarily immature insects, were collected during the sampling period. Of this total, 6,318 specimens were collected from the Rio Silveira, 9,570 from Marco, 8,222 from Divisa, and 4,851 from Antas (Tab. II).

The majority of the families identified were present in all four streams, but some particularities were observed; for example, Trichoptera (Philopotamidae), Diptera (Tipulidae), Hemiptera (Veliidae), Megaloptera (Corydalidae) and Collembola (Sminthuridae) occurred only in the Antas River. Annelida (Histriobdellidae) were found only in the Divisa River.

\section{Seasonal and Spatial Variation}

The Rio Marco contained the highest mean number of specimens, but the lowest richness and diversity (Tab. III). 
Table II. Absolute (n) and relative (\%) frequency of benthic macroinvertebrates in Silveira, Marco, Divisa and Antas Rivers, during the sampling period.

\begin{tabular}{|c|c|c|c|c|c|c|c|c|c|}
\hline \multirow[t]{2}{*}{ Macroinvertebrates } & \multirow[t]{2}{*}{ Family } & \multicolumn{2}{|c|}{ Silveira } & \multicolumn{2}{|c|}{ Marco } & \multicolumn{2}{|c|}{ Divisa } & \multicolumn{2}{|c|}{ Antas } \\
\hline & & $\mathrm{n}$ & $\%$ & $\mathrm{n}$ & $\%$ & $\mathrm{n}$ & $\%$ & $\mathrm{n}$ & $\%$ \\
\hline \multirow[t]{2}{*}{ Platyhelmintes } & Planariidae & 6 & 0.09 & 335 & 3.50 & 50 & 0.61 & 81 & 1.67 \\
\hline & Temnocephalida & 41 & 0.65 & 0 & 0.00 & 18 & 0.22 & 4 & 0.08 \\
\hline \multirow[t]{3}{*}{ Annelida } & Hirudinea & 48 & 0.76 & 0 & 0.00 & 2 & 0.02 & 1 & 0.02 \\
\hline & Oligochaeta & 32 & 0.51 & 0 & 0.00 & 1 & 0.01 & 2 & 0.04 \\
\hline & Histriobdellidae & 0 & 0.00 & 0 & 0.00 & 16 & 0.19 & 0 & 0.00 \\
\hline \multirow[t]{4}{*}{ Mollusca } & Ancylidae & 100 & 1.58 & 0 & 0.00 & 0 & 0.00 & 3 & 0.06 \\
\hline & Hydrobiidae & 166 & 2.63 & 0 & 0.00 & 137 & 1.67 & 0 & 0.00 \\
\hline & Ampullariidae & 60 & 0.95 & 0 & 0.00 & 8 & 0.10 & 0 & 0.00 \\
\hline & Bivalvia & 5 & 0.08 & 1 & 0.01 & 1 & 0.01 & 0 & 0.00 \\
\hline \multicolumn{10}{|l|}{ Arthropoda } \\
\hline Acarina & & 463 & 7.33 & 282 & 2.95 & 264 & 3.21 & 185 & 3.81 \\
\hline \multicolumn{10}{|l|}{ Hexapoda } \\
\hline \multirow[t]{3}{*}{ Collembola } & Isotomidae & 0 & 0.00 & 0 & 0.00 & 1 & 0.01 & 5 & 0.10 \\
\hline & Entomobyidae & 0 & 0.00 & 0 & 0.00 & 1 & 0.01 & 0 & 0.00 \\
\hline & Smynthuridae & 0 & 0.00 & 0 & 0.00 & 0 & 0.00 & 1 & 0.02 \\
\hline \multirow[t]{6}{*}{ Trichoptera } & Hydropsychidae & 481 & 7.61 & 19 & 0.20 & 25 & 0.30 & 13 & 0.27 \\
\hline & Hydroptilidae & 120 & 1.90 & 114 & 1.19 & 77 & 0.94 & 6 & 0.12 \\
\hline & Hydrobiosidae & 29 & 0.46 & 13 & 0.14 & 24 & 0.29 & 29 & 0.60 \\
\hline & Glossosomatidae & 12 & 0.19 & 20 & 0.21 & 13 & 0.16 & 27 & 0.56 \\
\hline & Leptoceridae & 29 & 0.46 & 102 & 1.07 & 48 & 0.58 & 89 & 1.83 \\
\hline & Philopotomidae & 0 & 0.00 & 0 & 0.00 & 0 & 0.00 & 1 & 0.02 \\
\hline \multirow[t]{4}{*}{ Diptera } & Chironomidae & 1,919 & 30.37 & 1,313 & 13.72 & 1,127 & 13.71 & 1,538 & 31.70 \\
\hline & Simuliidae & 600 & 9.50 & 100 & 1.04 & 66 & 0.80 & 146 & 3.01 \\
\hline & Psychodidae & 3 & 0.05 & 9 & 0.09 & 1 & 0.01 & 10 & 0.21 \\
\hline & Tipullidae & 0 & 0.00 & 0 & 0.00 & 0 & 0.00 & 1 & 0.02 \\
\hline Lepidoptera & Pyralididae & 27 & 0.43 & 236 & 2.47 & 137 & 1.67 & 5 & 0.10 \\
\hline \multirow[t]{3}{*}{ Coleoptera } & Elmidae & 114 & 1.80 & 353 & 3.69 & 191 & 2.32 & 335 & 6.91 \\
\hline & Psephenidae & 89 & 1.41 & 7 & 0.07 & 2 & 0.02 & 34 & 0.70 \\
\hline & Ptilodactylidae & 5 & 0.08 & 27 & 0.28 & 34 & 0.41 & 7 & 0.14 \\
\hline \multirow[t]{3}{*}{ Ephemeroptera } & Baetidae & 878 & 13.90 & 6,179 & 64.57 & 4,873 & 59.27 & 1,165 & 24.02 \\
\hline & Leptophlebiidae & 294 & 4.65 & 178 & 1.86 & 625 & 7.60 & 392 & 8.08 \\
\hline & Leptohyphidae & 437 & 6.92 & 181 & 1.89 & 273 & 3.32 & 441 & 9.09 \\
\hline \multirow[t]{2}{*}{ Plecoptera } & Gripopterygidae & 70 & 1.11 & 44 & 0.46 & 22 & 0.27 & 90 & 1.86 \\
\hline & Perlidae & 5 & 0.08 & 6 & 0.06 & 17 & 0.21 & 97 & 2.00 \\
\hline \multirow[t]{3}{*}{ Odonata } & Calopterygidae & 12 & 0.19 & 0 & 0.00 & 1 & 0.01 & 1 & 0.02 \\
\hline & Libelullidae & 1 & 0.02 & 0 & 0.00 & 0 & 0.00 & 0 & 0.00 \\
\hline & Coenagrionidae & 7 & 0.11 & 2 & 0.02 & 4 & 0.05 & 9 & 0.19 \\
\hline \multirow[t]{3}{*}{ Hemiptera } & Gerridae & 4 & 0.06 & 0 & 0.00 & 0 & 0.00 & 4 & 0.08 \\
\hline & Naucoridae & 10 & 0.16 & 5 & 0.05 & 1 & 0.01 & 12 & 0.25 \\
\hline & Veliidae & 0 & 0.00 & 0 & 0.00 & 0 & 0.00 & 1 & 0.02 \\
\hline Megaloptera & Corydalidae & 0 & 0.00 & 0 & 0.00 & 0 & 0.00 & 1 & 0.02 \\
\hline \multirow[t]{5}{*}{ Crustacea } & Copepoda & 53 & 0.84 & 2 & 0.02 & 49 & 0.60 & 45 & 0.93 \\
\hline & Cladocera & 112 & 1.77 & 13 & 0.14 & 12 & 0.15 & 0 & 0.00 \\
\hline & Ostracoda & 86 & 1.36 & 29 & 0.30 & 93 & 1.13 & 65 & 1.34 \\
\hline & Amphipoda & 0 & 0.00 & 0 & 0.00 & 0 & 0.00 & 1 & 0.02 \\
\hline & Decapoda Aeglidae & 0 & 0.00 & 0 & 0.00 & 8 & 0.10 & 4 & 0.08 \\
\hline Total & & 6,318 & 22.00 & 9,57 & 33.00 & 8,222 & 28.40 & 4,851 & 16.60 \\
\hline
\end{tabular}


Table III. Diversity indices of benthic macro invertebrates community based on samples collected during 2000-2001, in four rivers (N: total and mean abundance in parenthesis; S: richness; H': Shannon's index; 1/D Simpson's reciprocal index; DMG Margalef's index; EPT: number of family of Ephemeroptera, Plecoptera, Trichoptera; E: eveness).

\begin{tabular}{|c|c|c|c|c|c|c|c|c|}
\hline Stream & Season & $\mathrm{N}$ & $S$ & $\mathrm{H}^{\prime}$ & $1 / D$ & $\mathrm{DMg}$ & EPT & $E$ \\
\hline \multirow[t]{3}{*}{ Silveira } & Autumn & $1,788 \quad(894)$ & 20 & 1.91 & 4.98 & 2.93 & 8 & 0.64 \\
\hline & Spring & $1,363 \quad(681)$ & 20 & 1.82 & 4.38 & 2.99 & 9 & 0.60 \\
\hline & Summer & $3,167(1,583)$ & 26 & 2.43 & 8.36 & 3.49 & 9 & 0.74 \\
\hline \multirow[t]{3}{*}{ Marco } & Autumn & $3,227(1,613)$ & 12 & 1.39 & 2.78 & 1.58 & 6 & 0.55 \\
\hline & Spring & $1,342 \quad(671)$ & 12 & 1.05 & 1.79 & 1.79 & 6 & 0.42 \\
\hline & Summer & $5,001(2,500)$ & 19 & 1.16 & 1.82 & 2.30 & 7 & 0.40 \\
\hline \multirow[t]{3}{*}{ Divisa } & Autumn & $1,469 \quad(734)$ & 11 & 1.24 & 2.56 & 1.56 & 5 & 0.52 \\
\hline & Spring & $3,724(1,862)$ & 18 & 1.11 & 1.91 & 2.34 & 6 & 0.38 \\
\hline & Summer & $3,029(1,514)$ & 24 & 2.01 & 4.50 & 3.15 & 8 & 0.63 \\
\hline \multirow[t]{3}{*}{ Antas } & Autumn & $1,846 \quad(923)$ & 19 & 1.80 & 4.35 & 2.63 & 8 & 0.61 \\
\hline & Spring & $2,371(1,185)$ & 20 & 1.70 & 3.94 & 2.96 & 7 & 0.57 \\
\hline & Summer & $(317)$ & 12 & 1.66 & 4.07 & 2.08 & 5 & 0.66 \\
\hline
\end{tabular}

The Silveira and Antas rivers did not show significant seasonal differences in the diversity indices, although most indices were higher during summer season, for both rivers. However, significant seasonal differences were found to the Marco River in $\mathrm{D}_{\mathrm{Mg} \text {. }}(\mathrm{F}=18.99)$ and $\mathrm{S}(\mathrm{F}=9.39)$, and to the Divisa River in richness $(\mathrm{F}=17.62), \mathrm{H}^{\prime}(\mathrm{F}=9.44)$ and $\mathrm{D}_{\mathrm{Mg} .}(\mathrm{F}=10.89)$.

The result of the comparison between the diversities in the streams was significant. The Silveira and Marco rivers were dissimilar regarding $\mathrm{H}^{\prime}(\mathrm{F}=4.91), 1 / \mathrm{D}(\mathrm{F}=3.60), \mathrm{DMg}(\mathrm{F}=$ $5.47)$ and $\mathrm{E}(\mathrm{F}=4.47)$. The Silveira River had higher mean indices of diversity during the sampling period, followed by the Antas and Divisa rivers, and last by the Marco River.

The highest percentage of EPT occurred in the Divisa River (73.69\%), followed by the Marco (71.64\%), Antas (48.75\%) and Silveira (36.44\%) rivers.

\section{DISCUSSION}

The composition and the structure of the community of benthic invertebrates in the high-altitude mountain streams in southern Brazil have been little studied up to now, a circumstance that obstructs any attempt to compare the present results with those previously reported for this region. Investigations in streams in Ecuador and Denmark, identified as lowland streams by JACOBSEN et al. (1997), showed lower richness indices than those obtained in the present study. Results reported by BAPTISTA et al. (2001) from streams in southeastern Brazil indicated that the highest abundance and richness of benthic invertebrates occurred during a period of drought. The Tainhas River, also a part of the Taquari-Antas basin, however, shows consistently higher richness, reaching 36.67 in winter and 23.67 in spring (Bueno et al. 2003). The Silveira River had greater richness during the summer months (26), compared to the other streams. These results are similar to the richness levels of the families found in other South American streams.
The use of diversity indices in the analysis is appropriated and recognized as a good tool in preliminary evaluations of hydrographic drainages (CHARvet et al. 1998). In this sense, the value for $\mathrm{D}_{\mathrm{Mg}}$ in the Silveira River, as it describes the richness weighted against sample size, is very close to the data abtained from a nonpolluted stream in Lyon, France (Charvet et al. 1998). However, the use of diversity indices alone, can mask the results, leading to misinterpretations, notwithstanding the display of high diversity indices, as in the Silveira River. The use of other parameters such as the EPT can result in other explanations about what is occurring in the community structure.

The effect of stability of the limnetic environment and its relation with the structure of the community, more specifically the equitability, has been admitted as a key factor for the identification of biodiversity (JACOBSEN et al. 1997, JACOBSEN \& ENCALADA 1998). Values of E were higher during an unstable wet season in eight Ecuadorian highland streams (JACOBSEN \& ENCALADA 1998). In comparison to the equitability index values of the four sampled streams with the Tainhas River, a typical upland stream (BuENo et al. 2003), a stronger similarity to the Silveira River can be observed, followed by the Antas River. Our results showed a higher equitability in the Silveira River during the summer months, when rain was copious, surpassing $115 \mathrm{~mm}$ in December, typifying the instability of the environment.

Other investigations have described reductions in richness of non-tolerant EPT groups (Ephemeroptera, Plecoptera and Trichoptera) in agricultural streams (sensu LENAT \& CRAWFORD 1994) in connection with increases of richness and abundance of other taxa (Vuori \& Joensuu 1996, Sponseller et al. 2001). In three streams in the Piedmont ecoregion of North Carolina, U.S.A., the abundance of macroinvertebrates was greater in the summer, suggesting that input from energy sources was important for the sites where autochthonous productivity was 
considered an important energy source in agricultural streams (Lenat \& CraWford 1994). Furthermore, an increase in the abundance of Diptera Simuliidae was accelerated by an increase in organic and inorganic emissions (VUORI \& JoENSUU 1996). High abundance of these organisms has been followed by the increase of Oligochaeta and other Diptera in contaminated streams (LENAT \& CRAWFORD 1994). In polluted streams in southeastern Brazil, the prevalence of the dipterans Chironomus, known as indicators of environmental stress, was reported (MARques et al. 1999). Dipterans are tolerant organisms (LenAT 1993), and their abundance may indicated degraded conditions (MaUl et al. 2004). Our results confirm this information, because Diptera (Simuliidae and Chironomidae) predominated in the Silveira River, which suffers environmental stress from untreated runoff from the nearby Silveira village.

Among the constituents of the EPT groups, the family Baetidae was the most abundant during the spring and summer months. The second most abundant family of EPT was Leptohyphidae. On the other hand, the analysis of the benthic community showed that Chironomidae was the predominant family, during all sampling seasons. Again, these results confirm those for highland streams in Equador by JACOBSEN \& EnCAlada (1998). Baetidae and Chironomidae are good colonizers and grow rapidly, becoming dominating groups and adapting to changeable environments such as the Silveira River (Jacobsen \& Encalada 1998, Callisto et al. 2001b).

The Araucaria forests along some banks of the Silveira and Antas Rivers stabilize water temperatures, which is not the case in the Marco and Divisa Rivers, which are bare of bordering vegetation. Variations in temperature influence the life cycle of aquatic insects and can be the cause of reduction of their diversity. These fluctuations in temperature are directly associated with streams in non-forested areas, where waters may reach higher temperatures (SPONSELLer et al. 2001). Riparian vegetation can influence the physical processes in a stream, erosion, or the diversity of habitats (Whiting 2002). Our results seem to confirm those conclusions, since the Silveira and Antas Rivers did not show significant differences between the diversity indices through the seasons, emphasizing the importance of the natural marginal vegetation for the water courses. The input of plant material to the streams and the presence of macrophyte habitats in the substrata provide an ideal mesohabitat for the aquatic macroinvertebrates. This feature contributes to the increase of diversity and influences the distribution of invertebrates, as observed in a brook in the Paranapanema basin in Brazil (Uieda \& Gajardo 1996). These streams show, on the other hand, deeper stretches, with slow flow, and, therefore, continuous habitat transitions that affect the composition of their communities (PARdo \& Armitage 1997).

The lack of historical information about the benthic macrofauna does not permit any firm conclusion of the effect of rainbow trout, an exotic species introduced and re-introduced yearly in this region since 1983 , on the biodiversity in the streams. Our results did not indicate any perceptible impairment of diversity or abundance of benthic macroinvertebrates in the Silveira River. In addition to the possible predacious influence of the rainbow trout, this stream is subject to combined pressures from land-use practices and from urban and agricultural effluents. The input of organic matter to the watercourse may have favored the benthic macrofauna. The conservation of the native riparian vegetation along the banks of the Silveira River may also be responsible for the richness of macroinvertebrates observed during the sampling period.

The deficient documentation about freshwater biota in southern Brazil, combined with our inability to predict the structure of the benthic macroinvertebrate communities, is associated with our lack of knowledge about the historical utilization of the soil locally (Sponseller et al. 2001). The region is dominated by basalt and high organic matter content near the surface; low quantities of calcium, magnesium and potassium; low $\mathrm{pH}$ values and high content of changeable aluminum (FAO 1988). These characteristics result from the cold, wet climate, which favors buildup of organic matter. At the same time, the high rate of mineralization impoverishes the soil, which has been extensively used for cultivation of potatoes and apple trees. Stream headwater areas are susceptible to changes in the utilization of the surrounding areas and soil management in the drainage basin, as reported by researchers in North American and European countries (Lenat \& CraWford 1994, Vuori \& Joensuu 1996). Information is still lacking about possible changes in the chemical content of waters in southern Brazil resulting from the largescale introduction of Pinus plantations which replaced the natural vegetation, especially along the Divisa and Marco Rivers.

The relationship between the faunal composition and the functions of aquatic ecosystems is variable over both temporal and spatial scales, necessitating large-scale, long-term investigations (Lacroix \& Abbadie 1998). The variations examined here provide a preliminary characterization of the aquatic macrofaunal population dynamics, taking into account that species richness is a function of local and regional processes, the relative influence of which varies over time, as shown by MOUQUET et al. (2003) and VINSON \& Hawkins (2003). Studies in boreal forests in Finland clarified the important role of macroinvertebrates in processing allochthonous material, contributing to local decay, as well in the metabolic activity of streams and the transfer of energy from aquatic to terrestrial consumers (VUORI \& JOENSUU 1996). Therefore, the application of biomonitoring methods focusing on benthic macroinvertebrates is strongly recommended (Charvet et al. 1998) in streams, as an important tool for the evaluation of the biodiversity of terrestrial ecosystems in the region of "campos de cima da serra"in southern Brazil.

Our results show that highland streams in southern Brazil exhibit a diversity which is quite similar to other streams previously investigated. Although the diversity indices considered separately did not show a well-defined profile of the community structure, the EPT, examined in combination with those

Revista Brasileira de Zoologia 24 (2): 294-301, junho 2007 
indices, demonstrated that the Silveira River, with its high diversity, and the next-most-diverse Antas River are dominated by tolerant macroinvertebrate groups. This information suggests that these rivers are subject to moderate environmental stress, which requires further investigation.

\section{ACKNOWLEDGEMENTS}

We would like to thank FAPERGS (process 99/1064.1); CNPq (process 523408/96-0); PROPESQ/UFRGS and PIBIC/ CNPq. We also thank the coordinators of the project "São José dos Ausentes - Povo e paisagem". This is contribution number 490 of the Departamento de Zoologia, Instituto de Biociências, Pós-Graduação em Biologia Animal, Universidade Federal do Rio Grande do Sul.

\section{REFERENCES}

Batista, D.F.; D.F. Buss; L.F.M. Dorvillé \& J.L. Nessimian. 2001. Diversity and habitat preference of aquatic insects along the longitudinal gradient of the Macaé River Basin, Rio de Janeiro, Brazil. Revista Brasileira de Biologia 61 (2): 249-258.

Beisel, J.N.; P. Usseglio-Polatera; S. Thomas \& J.C. Moreteau. 1998. Stream community structure in relation to spatial variation: the influence of mesohabitat characteristics. Hydrobiologia 389: 73-88.

Boyero, L. 2003: Multiscale patterns of spatial variation in stream macroinvertebrate communities. Ecological Research 18: 365-379.

Bueno, A.A.P. \& G. Bond-Buckup. 2004. Natural diet of Aegla platensis Schmitt and Aegla ligulata Bond-Buckup \& Buckup (Crustacea, Decapoda, Aeglidae) from Brazil. Acta Limnologica Brasiliensis 16 (2): 115-127.

Bueno, A.A.P.; G. Bond-Buckup \& B.D.P. Ferreira. 2003: Estrutura da comunidade de invertebrados bentônicos em dois cursos d'água do Rio Grande do Sul, Brasil. Revista Brasileira de Zoologia 20 (1): 115-125.

Callisto, M.; M. Moretti \& M.Goulart. 2001a. Macroinvertebrados Bentônicos como Ferramenta para Avaliar a Saúde de Riachos. Revista Brasileira de Recursos Hídricos 6 (1): 71-82.

Callisto, M.; P. Moreno \& F.A.R. Barbosa. 2001b. Habitat diversity and benthic functional trophic groups at Serra do Cipó, southeast Brazil. Revista Brasileira de Biologia 61 (2): 259266.

Charvet, S.; A. Kosmala \& B. Statzner. 1998. Biomonitoring through biological traits of benthic macro invertebrates: perspectives for a general tool in stream management. Archiv fur Hydrobiologie 142 (4): 415-432.

Dolédec, S.; J.M Olivier \& B. Statzner. 2000. Accurate description of the abundance of taxa and their biological traits in stream invertebrate communities: effects of taxonomic and spatial resolution. Archiv fur Hydrobiologie 148 (1): 25-43.

FAO. 1988. Soil map of the world. Rome, Food and Agriculture
Organization of the United Nations, World Soil Resources Report 60, 138p.

Friberg, N.; M.J. Winterbourn, K.A. Shearer \& S.E. Larsen. 1997. Benthic communities of forest streams in the South Island, New Zealand: effects of forest type and location. Archiv fur Hydrobiologie 138 (3): 289-306.

Galdean, N.; M. Callisto \& F.A.R. Barbosa. 2001. Biodiversity assessment of benthic macro invertebrates in altitudinal lotic ecosystems of Serra do Cipó (MG, Brazil). Revista Brasileira de Biologia 61 (2): 239-248.

Governo do Estado de Santa Catarina. 1986. Atlas de Santa Catarina. Florianópolis, $176 \mathrm{p}$.

Harriman, R. \& B.R.S. Morrison. 1982. Ecology of streams draining forested and non-forested catchments in an area of central Scotlland subject to acid precipitation. Hydrobiologia 88: 251-263.

IPAgro. 1989. Atlas Agroclimático do Estado do Rio Grande do Sul. Porto Alegre, Governo do Estado do Rio Grande do Sul, Departamento de Pesquisa, Instituto de Pesquisas Agronômicas, Seção de Ecologia Agrícola, vol. 3, p. 211-326.

Jacobsen, D. \& A. Encalada. 1998. The macroinvertebrate fauna of Ecuatorian highland streams in the wet and dry season. Archiv fur Hydrobiologie 142 (1): 53-70.

Jacobsen, D.; R. Schultz \& A. Encalada. 1997. Structure and diversity of stream invertebrate assemblages: the influence of temperature with altitude and latitude. Freshwater Biology 38: 247-261.

KiKusHi, R.M. \& V.S. UiedA. 1998. Composição da comunidade de invertebrados de um ambiente lótico tropical e sua variação espacial e temporal, p. 157-173. In: J.L. Nessimian, \& A.L. CARVALHO. (Eds). Ecologia de insetos aquáticos. Rio de Janeiro, PPGE-UFRJ, Séries Oecologia Brasiliensis, vol. 5, 309p.

Lacroix, G. \& L. Arbadie. 1998. Linking biodiversity and ecosystem function: an introduction. Acta Oecologica 19 (3):189-193.

LEMOS, R.C. \& R. D SANTOS. 1986. Manual de descrição e coleta de solo no campo. Campinas, SBCS-SNLCS, 56p.

LENAT, D.R. 1993. A biotic index for the southastern United States: derivation and list of tolerance values, with criteria for assigning water-quality ratings. Journal of the North American Benthological Society 12: 279-290.

Lenat, D.R. \& J.K. Crawford. 1994. Effects of land use on water quality and aquatic biota of three North Carolina Piedmont streams. Hydrobiologia 294: 185-199.

LorenZ, A.; D.H.C.K. Feld \& P. Rolauffs. 2004. A new method for assessing the impact of hydromorphological degradation on the macroinvertebrate fauna of five German stream types. Hydrobiologia 516: 107-127.

MACAN, T.T. 1975. Guia de animales invertebrados de agua dulce. Espanha, Eunsa, Pamplona, 118p.

MARQUes, M.M. \& F.A.R. BARbosa. 2001. Biological quality of waters from an impacted tropical watershed (middle Rio Doce basin, southeast Brazil), using benthic macroinvertebrate commu- 
nities as an indicator. Hydrobiologia 457: 69-76.

Marques, M.M.; F.A.R. Barbosa \& M. Callisto. 1999. Distribution and abundance of Chironomidae (Diptera, Insecta) in an impacted watershed in south-east Brazil. Revista Brasileira de Biologia 59 (4): 553-561.

Maul, J.D.; J.L. Farris; C.D. Milam; C.M. Copers; S. Testa \& D.L. Feldman. 2004. The influence of stream habitat and water quality on macroinvertebrate communities in degraded streams of northwest Mississippi. Hydrobiologia 518: 79-94.

Melo, A.S. 2005. Effects of taxonomic and numeric resolution on the ability to detect ecological patterns at local scale using stream macro invertebrates. Archiv fur Hydrobiologie 164 (3): 309-323

Melo, A.S. \& C.G. Froehlich. 2001. Macro invertebrates in neotropical streams: richness patterns along a catchment and assenblage structure between 2 seasons. Journal of the North American Benthological Society 20 (1):1-16.

Merritt, R.W. \& K.W. Cummins. 1984. An introduction to the aquatic insects of North America. Dubuque, Kendall \& Hunt, $2^{\text {nd }}$ ed., 722p.

MMA. 2000. Avaliação e ações prioritárias para conservação da biodiversidade da Mata Atlântica e campos sulinos. Brasília Ministério do Meio Ambiente, Secretaria de Biodiversidade e Florestas, SBF, 40p.

MotTA, P.L. \& V.S. UiedA. 2005. Food web structure in a tropical stream ecosystem. Austral Ecology 30: 58-73.

Mouquet, N.; P. Munguia, J.M. Kneitel. \& T.E. Miller. 2003. Community assembly time and the relationship between local and regional species richness. Oikos 103: 618-626.

Pardo, I. \& P.D. Armitage. 1997. Species assemblages as descriptors of mesohabitats. Hydrobiologia 344: 111-128.

RebouÇAS, A.C. 1999. Água Doce no Mundo e no Brasil, p. 1-36. In: A.C. Rebouças; B. Braga; J.G. Tundisi (Eds). Águas doces no Brasil: capital ecológico, uso e conservação. São Paulo, Escrituras Editora, 717p.

RemPel, L.L.; J.S. Richardson \& M. HeAley. 2000. Macroinvertebrate community structure along gradients of hydraulic and sedimentary conditions in a large gravel-bed stream. Freshwater Biology 45: 57-73.

Rolan-Perez, G.R. 1988. Guía para el estudio de los macroinvertebrados acuáticos del Departamento de Antioquia. Fen, Colciencias, 217p.

Rosi-Marshall, E.J. \& B. Wallace. 2002. Invertebrate food webs along a stream resource gradient. Freshwater Biology 47: 129-141.

Salati, E.; H.M. Lemos \& E. Salati. 1999. Água e o Desenvolvimento Sustentável, p. 39-64. In: AC. RebouÇAS; B. Braga \& J.G. Tundisi (Eds). Águas doces no Brasil: capital ecológico, uso e conservação. São Paulo, Escrituras Editora, 717p.

Sponseller, R.A.; E.F. Benfield \& H.M. Valett. 2001. Relationships between land use, spatial scale and stream macroinvertebrate communities. Freshwater Biology 46: 1409-1424.

Tundisi, J.G.; T.M. Tundisi. \& O. Rocha. 1999. Ecossistemas de Águas Interiores. 153-192p. In: A.C. ReBouÇAS; B. BRAGA \& J.G. Tundisi (Eds). Águas doces no Brasil: capital ecológico, uso e conservação. São Paulo, Escrituras Editora, 717p.

Uieda,V.S. \& I.C.S.M. Gajardo. 1996. Macroinvertebrados perifíticos encontrados em poções e corredeiras de um riacho. Naturalia 21: 31-47.

Vinson, M.R. \& C.P. Hawkins. 2003. Broad-scale geographical patterns in local stream ensect genera richness. Ecography 26: 751-767.

VUORI, K-M. \& I.L. JoEnsuU. 1996. Impact of forewst drainage on the macro invertebrates of a small boreal headwater stream: do buffer zones protect lotic biodiversity? Biological Conservation 77: 86-95.

Whiting, P.J. 2002. Streamflow necessary for environmental maintenance. Annual Review of Earth and Planetary Sciences 30: 181-206.

Wright, J.F.; M.T. Furse; P.D. Armitage \& D. Moss. 1993. New procedures for identifying running-water sites subject to environmental stress and for evaluating sites for conservation, based on the macroinvertebrate fauna. Archiv fur Hydrobiologie 127 (3):319-326.

Received in 29.III.2006; accepted in 28.IV.2007. 